\title{
Fysisk kapasitet hos ekstremt premature
}

\author{
Barn født ekstremt prematurt har ca. $10 \%$ redusert fysisk kapasitet \\ i forhold til barn født til termin senere i livet, men med gjennomsnitts- \\ verdier innenfor normalen.
}

Barn født før 28. graviditetsuke, eller med fødselsvekt under $1000 \mathrm{~g}$, betegnes som ekstremt premature. Disse barna har en økt risiko for funksjonsnedsettelse og sykdommer senere i livet. Fysisk aktivitet reduserer risikoen for en rekke sykdommer, men barn og unge som er født prematurt ser ut til å være mindre aktive.

I mitt doktorgradsarbeid sammenlignet vi fysisk kapasitet hos ekstremt premature med barn født til termin i 1982-85 og 1991-92. De ble testet på tredemølle med syv års mellomrom ved henholdsvis 18 og 25 år og 10 og 18 år. Testene var signifikante og viste ca. $10 \%$ redusert fysisk kapasitet hos barn født ekstremt prematurt, hvor guttene utgjorde den største forskjellen. Gjennomsnittsverdiene var innenfor det som kan regnes som normalverdier.

Vi så på ulike forklaringsmodeller for denne forskjellen, men fant ingen sammen- heng med verken målt lungefunksjon eller forhold i nyfødtperioden. Vi fant derimot en positiv assosiasjon mellom fysisk kapasitet og fysisk aktivitet på fritiden, med unntak av hos 10-åringene. Denne sammenhengen var lik hos ekstremt premature og terminfødte, og utviklingen av fysisk kapasitet fra 10 til 18 år og 18 til 25 år var lik i begge gruppene. Dette er et positivt funn som kan tyde på at ekstremt premature er trenbare, men dette må undersøkes nærmere i intervensjonsstudier.

Fysisk aktivitet er helsefremmende og forebyggende, og normal fysisk kapasitet ser ut til å være mulig å oppnå for denne sårbare gruppen. Det er derfor viktig å legge til rette for god fysisk aktivitet slik at mestring oppnås og god helse fremmes hos ekstremt premature.

\section{Hege Synnøve Havstad Clemm} hclemm@gmail.com

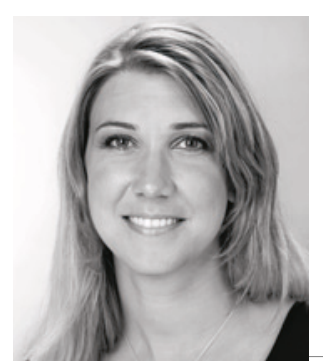

Hege Synnøve Havstad Clemm. Foto: Anne Sidsel Herdlevær

Disputas

Hege Synnøve Havstad Clemm disputerte for ph.d.-graden ved Universitetet i Bergen 28.8. 2015. Tittelen på avhandlingen er Exercise capacity after extremely preterm birth - Development from childhood to adulthood.

\section{Brystsmerter på legevakten}

\section{Brystsmerter ser man hyppig ved akutt sykdom utenfor sykehus, men det er stor variasjon i hvordan legevaktleger diagnostiserer og behandler. Hånd- tering av pasientene henger sammen med legenes «toleranse for risiko».}

Hovedutfordringen ved brystsmerter utenfor sykehus er å skille alvorlige tilstander, som akutt koronarsyndrom, fra mindre alvorlig sykdom, med begrensede diagnostiske verktøy. Målet for doktorarbeidet var å utvikle ny kunnskap om hvordan legevaktleger diagnostiserer og behandler pasienter med brystsmerter, og i hvilken grad legenes håndtering hadde sammenheng med deres «toleranse for risiko».

Avhandlingen bygger på to studier. I den første studien undersøkte vi 5000 «røde responser» håndtert av AMK-sentraler, der vi så på de $22 \%$ av pasientene som hadde brystsmerter. I den andre studien gjennomførte vi 100 strukturerte intervjuer med leger ved fire legevakter.

Den første studien viste at de fleste pasientene med brystsmerter ble innlagt, men bare en firedel var alvorlig syke. AMK-sentralene hadde betydelige vansker med å velge riktig hastegrad.

I den andre studien fant vi et stort spekter av årsaker til pasientenes brystsmerter, og under halvparten ble innlagt med mistanke om akutt hjerteinfarkt. Vi fant stor variasjon i hvilken grad legene diagnostiserte $i$ tråd med gjeldende retningslinjer. Det varierte også betydelig hva som påvirket legenes valg om pasientene skulle innlegges eller ikke. Det var ingen større forskjeller $\mathrm{i}$ «toleranse for risiko» ved undersøkelse av legens kjønn eller erfaring.

Funnene tyder på at det er behov for økt oppmerksomhet rundt diagnostikk av brystsmerter på legevakt, med særlig søkelys på risikovurdering for hjerteinfarkt og legens egen «toleranse for risiko».

Robert A. Burman

robert.burman@uni.no

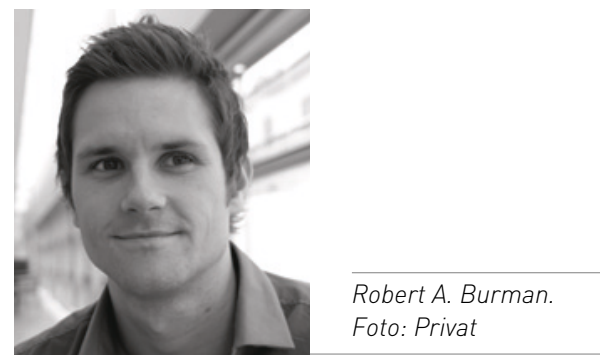

Disputas

Robert A. Burman disputerte for ph.d.-graden ved Universitetet i Bergen 12.6. 2015. Tittelen på avhandlingen er Chest pain out-of-hours. Prospective studies on diagnostics and management in out-of-hours emergency primary health care in Norway. 